\title{
Written and Spoken Language in Igbo Cultural Milieu: A Philosophical Approach
}

\author{
Ignatius Nnaemeka Onwuatuegwu PhD \\ Department of Philosophy, Faculty of Arts, Nnamdi Azikiwe University Awka, Nigeria
}

\begin{abstract}
Aristotle in his De Interpretatione sketches how words are related to things through the mind. It is the spoken word that brings to light the secret intentions of the human heart. Hence the Igbo people usually say that the spoken word is the human mind made visible. In our contemporary society, the effects of many related spoken word problems are often misconstrued as either attacks from the malevolent spirits or as the machinations of the evil people. The spoken words can create as well as destroy. There is, therefore, a serious need to create the awareness and enlightenment in this regard to the grassroots. This work will, therefore, attempts to bring out the concept of the spoken language in Igbo cultural milieu, as a phenomenon to a philosophical scrutiny and, hence to provide the much needed literature in the field. Hence, the work intends to bring some enlightenment concerning the Igbo concept of the spoken words. This enlightenment will as well create awareness on the effectiveness and efficaciousness of the spoken words both in the positive and the negative dimensions, as well as the reason Igbo-African prefer spoken words to the written words. The researcher primarily uses philosophic techniques as a method to achieve the purpose of the study.
\end{abstract}

KEYWORDS: Cultural milieu, Language, Thought pattern, Spoken words, Written words.

\section{GENERAL INTRODUCTION}

A people's manner of comprehending reality unavoidably influences their general attitude to life including their conception and application of words. Consequently, the ancient Igbo were not literate in terms of the Western system of education. Nevertheless, they had their own method of storing their Philosophical propositions and moral norms and codes. However, there was no philosophical, religious or moral book that should be considered as the compendium of their philosophical, religious or moral and cultural conceptions. For the lack of a standardized way of keeping records, perhaps, contributes to the innate regard an Igbo man has for spoken language.

For the westerners, the spoken word flies, but the written word remains. On the contrary, however, an Igbo-African strongly upholds that the spoken words outlive the person that utters them. This can be seen in such a statement as "If a statement is forgotten by the one who made it, the one to whom the statement is addressed will surely not forget".

Nonetheless, the sayings of an individual person can go into extinction or oblivion and as a result emptied into the communal sayings of the community. Consequently, the Igbo-African society is a communalistic community in which an individual exists only in a community (Onwuatuegwu; 2010). Little wonder, the Igbo essentially values communalism as an essential part of their lives. The individual persons in a community with time shall come to pass, while the community will remains. In the same vein, the sayings of an individual person in the community shall, with time, culminate into the communal adage- sayings of the forefathers. Hence, for the Igbo people, man necessarily discovers or becomes aware of his or her humanity only in the community of persons (Onwuatuegwu, 2021). For the lack of a systematized and standardized method of record keeping, it is consequently very diffic ult to identify the spoken words of an individual forefather from a particular stage in history or the sayings of a forefather of a distant past.

The Influence of the Igbo-African Conceptual Interpenetration of the Physical and the Metaphysical and Language Use Ikenga Metuh succinctly summarises on the fact of the Igbo-African preference of spoken language to the written language, thus: Most traditional African societies did not develop the art of writing. So in no traditional African society were the tenets of their beliefs found collected and presented in any written form. The absence of written has enhanced the importance of oral traditions as a means of preserving and transmitting cherished traditional religious beliefs and practices (Metuh, 1991). 


\title{
International Journal of Current Science Research and Review
}

\author{
ISSN: 2581-8341
}

\section{Volume 05 Issue 02 February 2022}

DOI: 10.47191/ijcsrr/V5-i2-08, Impact Factor: 5.825

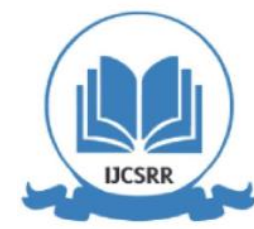

The system of oral tradition is not without some sort of short comings. For instance, in the preservation and conservation of traditional beliefs through oral tradition, it is not always possible, if possible at all, to identify the name of the initiator of a propoundment and the particular idea of a particular individual person (Onwuatuegwu, 2011).

For an Igbo, however, the spoken word of an individual person is derived from the divine itself, hence the saying that man's spoken word is the voice of the unseen (the invisible God). This is as a result of an Igbo man's conception of man as the mouthpiece of God himself. As the Supreme divinity knows no perishability or mutation, the spoken word is believed to endure as it directly derived from God whose nature it is to endure. Hence, from the already narrated understanding, an Igbo man conceives a written word as inactive and ineffective letters unless it is endowed with the power of the spoken word. In other words, it is the power of the spoken word that can revitalize the written word, without which it will lie waste. Onwuatuegwu (2011) maintains that in written language, the choice of words can alter the potency of a statement, whereas in a spoken language, the person that is addressed will as long as he or she lives, readily remember and can repeat the same as it was said, and as such retains the first-hand nature of the information.

\section{CULTURE AND THE POWER OF LANGUAGE}

Culturally speaking, people exhibit varied and diverse attitudes to life. The general attitude of a people to life is in turn basically determined by their culture. Culture according to I. N. Onwuatuegwu (2011) is a raw material with which the philosophical axioms of a particular people are developed. This very fact is the relationship between culture and philosophy. Culture as people's way of life, part of which is language, conditions and determines the importance a particular people attach to spoken or written words, the implication as well as the application they make of words. Therefore, there are some cultural dispositions to life that influence language and use of words, its Implication and application. Hence, I. N. Onwuatuegwu emphasizes, therefore, that;

A people or a race is differentiated from every other races not on ontological basis or on the basis of colour of the body but on the socio-cultural ground. Ontologically all men are the same and have but one human culture. Therefore, what identify a race or a tribe or a group of people is a socio-cultural difference and not an ontological difference (Onwuatuegwu, 2021)

P. Ogugua emphatically and categorically postulates that the more a people neglect or toy with their culture which is fundamentally the basis of their life, the more they will be disconnected from the basic ontological and metaphysical principles which ground and do express this culture (Ogugua, 2003).

To start with, the manner in which a person from an individualistic cultural perspective sees life and applies words will surely never be the same way a person from a communalistic cultural perspective would like to see life and applies words. Meanwhile, whether an individual is individualistic or a communalistic person determines the notion, values, beliefs, behavioral, and manner of approach the individual in question is likely to adopt.

What matters first for an individualistic person is his personal needs and not the common good. On the other hand, a person from a communalistic cultural background emphasizes more on the societal identity, survival or progress, notions, beliefs, values, customs, traditions, rights and in fact the common good of the community. This is so because a communalist believes that the good and the survival of the community guarantees the good and the survival of the individuals that consisted the community. What benefits the group equally benefits the individual (Gold, 2005).

In contrast to the individualistic culture in which only the biological family members matter, the communalistic cultural system, the family comprises multiple generations and extended family which include adult, children, uncles, aunts, grandparents and grandchildren and great grandchildren. These mentioned members of the family often live harmoniously together (Gold, 2005). Igbo race are among the communalistic nations. This, perhaps, might be the reason Uchendu opines that Community spirit is very strong among the Igbo (Uchendu, 1996). They are naturally religious and their religious aspects of life play an indispensable role in fostering peaceful coexistence among them. On this aspect of Igbo people's religiosity, G. U. Dine without mincing words says that: The Igbo, like their African neighbours, are very religious in the sense that they identify their existence with religion and move and breathe in it. It is not an exaggeration to say that the Igbo see religion in everything around them, for everything is created by Chukwu (God). These things manifest Chukwu's handiwork. All activities- religious and political- are regarded as the design of Providence for national existence (Dine; 1983). 


\section{International Journal of Current Science Research and Review}

ISSN: 2581-8341

Volume 05 Issue 02 February 2022

DOI: 10.47191/ijcsrr/V5-i2-08, Impact Factor: 5.825

IJCSRR@ 2022

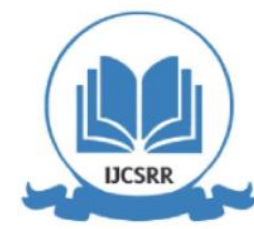

www.ijcsrr.org

M. E. N. Njaka in line with the above statements succinctly affirms that religion is so fundamental to the Igbo people that it plays a vital function in their life to such an extent that it penetrates all facets of their community. The culture and the political system of the Igbo people can be comprehended only with reference to their religion (Njaka; 1974)

This is achieved through communal and meaningful argumentation and cordial dialogue which in turn fosters a harmonious relationship in the community (Gopin, 2000). Gold (2005) affirms that the watchword for the communalistic society is "uniteed we stand, divided we fall ". Following the same line of thought I. N. Onwuatuegwu (2011) maintains that whatever is unanimously stated stands. In other words, the general words of a people are more important than those of the individuals. The spoken word of an individual stands the test of time as long as it conforms with the norms and values of the group or the community.

In a high-context culture such as in Igbo-Africa, speech conveys not just what the statements portray, but also their implications, or inference and the listener gets the message which the speaker intends to convey. This is possible because of the shared experience, connection and history. Gold, therefore, affirms:

In a high-context culture, much of the meaning of a communication is already "programmed" into the receiver, of the message as a result of the shared experience, connection and history of the sender and the receiver (Gold, 2005).

More so, E. T. Hall identifies monochronism and polychronism as two time orientations that vary and affect communication across different cultures (Hall, 1989). In monochronic culture, time is conceived as linear, quantifiable, and as such in a limited supply. Consequently, therefore, time is considered variable or as it is usually said "Time is money ". Written word is, therefore, valued more in a monochronic culture. One on one discussion may be considered time consuming. Hence, written word is preferred to spoken word as one can go through the written word at one's leisure.

In contradistinction to monochronic culture, the polychronic culture visualises time as limitless, cyclical and, hence, unquantifiable. Time according to Onwuatuegwu, therefore, is adjust and readjust as to suit the needs of the people (Onwuatuegwu, 2011). A polychronist has no problem with plenty of words. Hence, in polychronic culture as among the Igbo, words are much valued. To make a point in such a culture, one has to apply plenty of words, first to clear the ground; after which the point is then made.

More still, another aspect of culture that affects language is that of "power distance" (Hofstede, 1997). The concept of power distance implies the extent to which wealth, availability of education, prestige and other essentialities of life are unevenly distributed and to which extent those that are not in authority are disposed to accept directives from those that are in authority.

In a low power distance culture, those in authority usually minimize the gaps between them and their subordinates. Hence, inequality is considered man-made and should be allowed to persist. The subordinates are free to take initiative and are encouraged to do so. In like manner, criticism of those who are in authority is accepted as appropriate.

In a high power distance culture, the power and status inequalities are welcome and considered as natural. Shippee in this regard opines that:

The prevailing attitude is that some individual will have more power and influence than others. Those with power emphasize their status and avoid delegating or sharing it and distinguish themselves from those without power or with less power. Criticism or disagreement with those in authority by subordinates is viewed as undesirable (Shippee).

Consequently, in a high power distance culture, obedience to and respect for elders are considered essential. This brings about closer family ties and dependence is encouraged by parents on the members of their family. In such a culture, one is advised to shew one's word before expression.

Igbo-African has a high power distance culture. In Africa with particular interest in Igbo cultural milieu, inequalities in power and status are taken as natural. This is demonstrated in the sayings: "All fingers are not equal", and "All trees in the forest are not equal in all aspects ". This, perhaps, could serve as reason, many African with reference to Igbo scientists and metaphysicians failed to share their secrets with others and as a result did not disseminate their secret wisdom to the younger generations only to maintain their special-ness and distance from others (Onwuatuegwu, 2011). Admittedly, because of the African high power distance culture, the spoken words or instructions of those in authority such as priests, dibias, elders and parents are not something to be toyed with. From the religious point of view, different religions of the world in various ways have expressed the importance of words and language. It is with words that different religions communicate their thoughts and it is with words they commune with God in prayer. Invariably, words are not only employed to convey the truth or to heal, but words are equally used to obscure and deconstruct reality, as it pertains to the philosophical, religious, social and ritual phenomena found within the context of Igbo-African cultural milieu. 


\section{International Journal of Current Science Research and Review}

ISSN: 2581-8341

\section{Volume 05 Issue 02 February 2022}

DOI: 10.47191/ijesrr/V5-i2-08, Impact Factor: 5.825

\section{UNAVOIDABILITY OF LANGUAGE IN HUMAN EXISTENCE}

The issue of language is one of the phenomena that is unavoidable in the human context. With words we communicate with the Supreme divinity in prayer. With words we bless and with the same words we curse. Spoken word can build and at the same time can destroy. It brings persons or communities into a loving union, but can as well disunite them. No day has ever passed without one coming across one or two problems or brouhaha that arose either from wrong application of words or from harshly used words. The essentiality of spoken words made J. Annas and L. Judson (1996) emphasize that:

If an utterance is significant, then there must be a thought which it arouses, and, since that thought must be a thought of some thing, there must be a thing for which the word stands.

By the above statements, Annas \& Judson imply that words are symbols that present and represent realities other than the mere spoken words. In that line of thought, words connect us to realities through the mind (thought). Hence, nothing in the human language that is not an expression of the human thought, and nothing in the human mind that is not represented somewhere in reality. Little wonder Aristotle maintains that spoken utterances are nothing but the expressions of thought or affections in the soul (Plato). All these culminate in the Igbo saying that human spoken words are the human thought (mind) made visible.

Man is debilitated on daily basis as a result of either misinterpretation of spoken words or wrong application of words. Consequently, various spoken words related problems are often misconstrued either as attacks from the evil spirits or as the machinations of the evil men. This is clearly the result of the contemporary man losing touch with reality and, hence, dwelling on mere speculation and mere superstitions. This very fact possibly made Onwuatuegwu to concludes that:

..., the knowledge of the really real and the interior manifestation of reality is gradually eluding the modern man.

Consequently, as the modern man lacks the interior knowledge of things, he is solely dependent on the mere speculations and superstitions. Modern man, therefore, needs that grace that will enable him to open up to the divine spack that will in turn ignite man's rational mind into creativity and productivity (Onwuatuegwu, 2022).

Words of the mouth either by way of curse or magic can shatter the balance between the psychological and the spiritual dimensions of an individual person, which Invariably brings about some kinds of disjointedness in the physical man. Whenever disequilibrium occurs between the spiritual and the psychological dimensions of an individual, it always affects or manifests in the physical. Hence, many patients who are suffering from psycho-somatic illnesses usually flock around the houses of either the traditional medicine men, prophets and prophetesses, pastors and many healing houses. These popular healers have always already made answers and solutions for their unsuspecting patronizers. However, the major means of healing is by applying words of blessing on the patients; giving them assurance of a better tomorrow; advising them to be cautious with their neighbours and family members who might be working for their downfall. This can at times be complimented with carrying out some form of sacrifices or expiatory rites with some forms of magicalised dance and a host of other things just to work on the psyche of their patients.

\section{CONCLUSION}

Having observed the notable effectiveness and efficaciousness attributed to spoken word in Igbo-African milieu, having seen the confusion and contradictions which could result from the manipulations and misuse of spoken words and more still, the constructive as well as the destructive effects of spoken words in Igbo-African milieu, it is necessarily important to be cautious about how one speaks and the choices of words in one's conversation with another. Words are active and alive. Spoken words are dynamic and very creative.

\section{REFERENCES}

1. Annas, J. \& Judson, L. (Eds.) (1996) "Aristotle's De Interpretatione Contradiction and Dialectic", Oxford University Press, New York.

2. Dine, G. U. (1983) "Traditional Leadership as Service Among the Igbo of Nigeria, (Anthropo- Theological Approach)", Pont Universita Lateranense, Rome.

3. Gold, J. A. (2005) Through a Cultural Lens: How Cultural Values Shape our Disputing process, J. Disp, Resol, New York.

4. Gopin, M. (2000) From Eden to Armageddon, Oxford University Press, Oxford.

5. Hall, E. T. (1989) The Dance of Life: The Other Dimension of Time, Cambridge University Press, New York. 


\section{International Journal of Current Science Research and Review}

ISSN: 2581-8341

Volume 05 Issue 02 February 2022

DOI: 10.47191/ijesrr/V5-i2-08, Impact Factor: 5.825

IJCSRR@ 2022

6. Hofstede, G. (1997) Culture and Organisations: Software of the mind 5.

7. Metuh, E. I. (1991) African Religions in Western Conceptual Schemes: The Problem of Interpretation, Ehindero limited, Jos.

8. Njaka, M. E. N. (1974) "Igbo Political Culture", Northwestern University Press, Evanston.

9. Ogugua, P. (2003) "Igbo Understanding of Man: A Step to Understanding Igbo Metaphysics and Fostering a True Philosophy of Life", Penmark Publishers, Nigeria.

10. Onwuatuegwu, I. N. (2011) The Power of the Word in Igbo Metaphysics: A Philosophical Investigation, Rex Charles and Patrick Limited, Nimo.

11. Onwuatuegwu, I. N. (2010) "The Concept of Reincarnation in Igbo Ontology: A Philosophical Appraisal", Rex Charles and Patrick publications, Nimo.

12. Onwuatuegwu, I. N. (2022) "Resolution of the Tensions between the demands of the Christian Faith evident among the Igbo-African Youths and some Occurrences in Life in relation to Culture:A Philosophical perspective", Asian Journal of Advances in Research, Vol. 12(3): 43-50.

13. Onwuatuegwu, I. N. \& Nwagu, N. B. (2021) "The Igbo Communalism: A Panacea to the Problem of the Nigerian SocioPolitical System (A Philosophical Reflection)", The American Journal of Humanities and Social Sciences Research, Vol. 04, Issue 03, pp. 55-60.

14. Plato, Republic, $511 \mathrm{~d}$.

15. Shippee, R. S. , Blessed are the "pacemakers ": Faith-Based Approaches to Dispute Resolution, 9(ILSA. Int'1 and comp. L.), pp.298-300).

16. Uchendu, V. C. (1996) "The Igbo of Southeast Nigeria", Holt, Reinehart and Winston, London.

Cite this Article: Ignatius Nnaemeka Onwuatuegwu PhD (2022). Written and Spoken Language in Igbo Cultural Milieu: A Philosophical Approach. International Journal of Current Science Research and Review, 5(2), 358-362 